\title{
Effects of freezing on length and mass measurements of Atlantic cod Gadus morhua in
} the Baltic Sea

McQueen, K.; Mion, M.; Hilvarsson, A.; Casini, M.; Olesen, Hans Jakob; Hüssy, Karin; Radtke, K.; Krumme, U.

Published in:

Journal of Fish Biology

Link to article, DOI:

$10.1111 / \mathrm{jfb} .14171$

Publication date:

2019

Document Version

Peer reviewed version

Link back to DTU Orbit

Citation (APA):

McQueen, K., Mion, M., Hilvarsson, A., Casini, M., Olesen, H. J., Hüssy, K., Radtke, K., \& Krumme, U. (2019). Effects of freezing on length and mass measurements of Atlantic cod Gadus morhua in the Baltic Sea. Journal of Fish Biology, 95(6), 1486-1495. https://doi.org/10.1111/jfb.14171

\section{General rights}

Copyright and moral rights for the publications made accessible in the public portal are retained by the authors and/or other copyright owners and it is a condition of accessing publications that users recognise and abide by the legal requirements associated with these rights.

- Users may download and print one copy of any publication from the public portal for the purpose of private study or research.

- You may not further distribute the material or use it for any profit-making activity or commercial gain

- You may freely distribute the URL identifying the publication in the public portal 


\section{REGULAR PAPER}

Effects of freezing on length and mass measurements of Atlantic cod Gadus morhua in the Baltic Sea

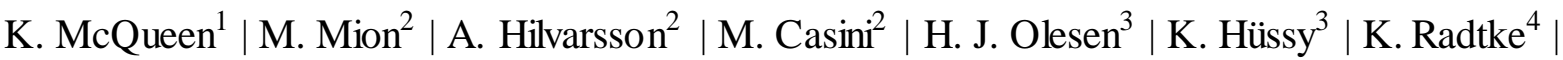
U. Krumme ${ }^{1}$

${ }^{1}$ Thünen Institute of Baltic Sea Fisheries, Alter Hafen Süd 2, Rostock, Germany

${ }^{2}$ Swedish University of Agricultural Sciences, Department of Aquatic Resources, Institute of Marine Research, Lysekil, Sweden

${ }^{3}$ Technical University of Denmark, National Institute of Aquatic Resources, Kgs. Lyngby,

Denmark

${ }^{4}$ National Marine Fisheries Research Institute, Ul. Kołlątaja 1, Gdynia, Poland

\section{Correspondence}

K. McQueen, Thünen Institute of Baltic Sea Fisheries, Alter Hafen Süd 2, 18069 Rostock, Germany

EMail: kate.mcqueen@thuenen.de

\section{Funding information}

This study was funded by BalticSea2020 (www.balticsea2020.org) through the project Tagging Baltic cod (TABACOD).

This article has been accepted for publication and undergone full peer review but has not been through the copyediting, typesetting, pagination and proofreading process which may lead to differences between this version and the Version of Record. Please cite this article as doi: $10.1111 /$ jfb.14171 


\begin{abstract}
An aggregated sample of 925 Atlantic cod Gadus morhua collected by four countries in different regions of the Baltic Sea during different seasons were measure (total length, $L_{\mathrm{T}}=$ 161-890 mm and weighed (mass, $M=45-6900 \mathrm{~g}$ ) both before freezing and after defrosting. The cod were found to decrease significantly in both $L_{\mathrm{T}}$ and $M$ following death and frozen storage. There was an average $( \pm \mathrm{SD})$ change in $L_{\mathrm{T}}$ of $-2.91 \%( \pm 0.05 \%)$ following freezing, independent of starting $L_{\mathrm{T}}$. Total $M$ changed by $-2.65 \%( \pm 0.14 \%)$, independent of starting mass. Shrinkage of $L_{\mathrm{T}}$ and $M$ did not differ significantly between 1 and 4 months frozen storage, though $L_{\mathrm{T}}$ shrinkage was significantly greater after 1 or 4 months in the freezer compared with after 5 days. There was significant variation in $L_{\mathrm{T}}$ and $M$ shrinkage between regions of capture. A significant negative relationship between condition of $\operatorname{cod}$ and $L_{\mathrm{T}}$ or $M$ change was also observed. Equations to back-calculate fresh $L_{\mathrm{T}}$ and $M$ from thawed $L_{\mathrm{T}}, M$ and standard length $\left(L_{\mathrm{S}}\right)$, gutted $L_{\mathrm{T}}$, gutted $L_{\mathrm{Tg}}$ and gutted mass $\left(M_{\mathrm{g}}\right)$ are provided.
\end{abstract}

\title{
KEYWORDS
}

Baltic Sea, cod, freezing, Gadus morhua, measurement bias, shrinkage

\section{1 | INTRODUCTION}

Body length and mass measurements are a vital component of studies on fish growth and condition and are necessary input data for most fish stock assessments. It is frequently necessary to preserve wild-caught marine fish for subsequent analysis in the laboratory and a common and convenient method for storing whole adult fish is freezing. The process of freezing causes changes in the muscle tissue of fish (Johnston et al., 1994, Mørkøre \& Lilleholt, 2007) and has been reported to result in reductions in both length and mass of many 
fish species (Halliday \& Roscoe, 1969, Buchheister \& Wilson, 2005, Ogle, 2009). Such changes clearly have the potential to bias subsequent estimates of growth and condition and should therefore be corrected for.

Atlntic cod Gadus morhua L. 1758 in the eastern Baltic Sea is a commercially important species for which the stock assessment was recently compromised due to uncertainties surrounding the estimation of age, growth and mortality (Eero et al., 2015). In addition, the proportion of low-condition eastern Baltic cod is relatively high (Eero et al., 2015, Casini et al., 2016) and fish in this population are now thought to be particularly slow growing (Hüssy et al., 2018). International tagging activities are ongoing in an attempt to estimate growth rates of cod in this region without relying on questionable age estimation. Most fish from this tagging project (TABACOD; www.tabacod.dtu.dk) are recaptured by commercial fishers, anglers or research vessels and are generally stored in a freezer for several weeks before being examined biologically at a research institute. Therefore, robust conversion equations are required to predict the fresh length at recapture from a defrosted individual before the measurements can be used for growth estimation.

Although there are several published examples of shrinkage rates of various fish species, the variability in shrinkage necessitates the estimation of species-specific conversion factors (Halliday \& Roscoe, 1969, Ogle, 2009). There are already estimates of length and mass shrinkage of frozen cod available from an experiment using limited sample sizes from the north-west Atlantic Ocean (Halliday \& Roscoe, 1969). However, without further investigation, these cannot be assumed to apply to Baltic Sea cod, a genetically distinct stock that inhabits a unique brackish water sea.

Robust sampling of cod from the southern Baltic Sea provided the data required to estimate length and mass shrinkage conversion equations. The data were used to assess 
whether time spent frozen affected shrinkage. The relationships between shrinkage and sampling region, condition and size of the fish were also evaluated.

\section{2 | METHODS}

\subsection{Data collection}

Samples of Baltic cod were collected 2017-2018 by four Baltic Sea countries (Germany, Denmark, Poland and Sweden) by trawling from commercial fishing or research vessels. Each country trawled for cod within their national waters in the Arkona Basin, Bornholm Basin, Gdańsk Bay and Hanö Bay regions of the Baltic Sea, respectively, covering the current main distribution of the eastern Baltic cod stock (Hüssy et al., 2016, Orio et al., 2019) within International Council for the Exploration of the Sea (ICES) subdivisions 24-26 (Figure 1). Two genetically distinct but morphometrically similar populations of cod inhabit the Baltic Sea (referred to as the Western and Eastern stocks) and their ranges overlap with considerable stock mixing occurring predominantly in subdivision 24 (Hüssy et al., 2016, Hemmer-Hansen et al., 2019, Weist et al., 2019). It is therefore likely that samples consisted of a mixture of Western and Eastern Baltic cod. Each country collected samples at least twice, during different seasons of the year, to ensure relatively balanced seasonal coverage (Table 1). Dependent on the length distribution available from the catch, two fish per $10 \mathrm{~mm}$ length class $(160-700 \mathrm{~mm})$ were collected for the experiment. For less abundant catches or length classes, two fish per $50 \mathrm{~mm}$ were collected.

Whenever possible, measurements of total length $\left(L_{\mathrm{Ta}}\right)$ and total mass $\left(M_{\mathrm{Ta}}\right)$ were taken from live fish (subscript a). $L_{\mathrm{Ta}}$ measurements were recorded to the nearest $\mathrm{mm}$, measured using a millimetre measuring board (Swedish, Danish and Polish samples), or 
estimated from a centimetre measuring board (German samples). $M_{\mathrm{Ta}}$ was measured to the nearest g, with scales that differed among sampling countries: Germany, Marel (www.marel.com) M1100 scale (weighing range 1.5-3 kg, accuracy 0.5-1g); Denmark, Mettler (www.mt.com) Toledo ICS429g-A6 (maximum weighing capacity $6 \mathrm{~kg}$, accuracy 0.5 g); Sweden, POLS (Lorimar, www.lorrimar.co.uk) P-15/S-182 (weighing range $20 \mathrm{~g}-3 \mathrm{~kg}$, accuracy $1 \mathrm{~g}$ ); Poland POLS S-120-3 (weighing range $2 \mathrm{~g}-0.3,1,3 \mathrm{~kg}$, accuracy $0.2,0.5,1 \mathrm{~g}$, respectively). When measuring, mass, if the value shown on the scale fluctuated due to the movements of the vessel, then the fish was left on the scale until the measurement stabilised, or if stabilisation did not occur, the most commonly displayed value (judged by the measurer) was recorded. This issue generally did not occur on the Swedish and Polish vessels, as a motion compensated marine weighing scale was used. Owing to time constraints on research vessels, or because of poor survival of trawled fish, it was not always possible to measure live fish. Therefore, in some cases measurements were taken only on fish that had been dead for c. 1 hour (subscript d; $n=105$ ). A subsample of cod were measured live, killed and measured again 1 hour after first measurement $(n=494)$.

After measurement, fish were individually labelled and frozen. The freezer temperature on board the vessel varied slightly between sampling countries $\left(c .-20^{\circ} \mathrm{C}\right.$ on German research vessel, $-18^{\circ} \mathrm{C}$ on all other vessels). After the research cruise, frozen cod were transferred to a freezer in the respective research institutes (freezer temperature in Denmark and Poland: $-18^{\circ} \mathrm{C}$; Germany: c. $-20^{\circ} \mathrm{C}$; Sweden: -25 to $\left.-30^{\circ} \mathrm{C}\right)$. From each sampling event, one fish per length class was defrosted and measured after one month of frozen storage and a second fish per length class was defrosted and measured after 4 months of frozen storage. One and 4 months represent typical times that recaptured tagged cod could be expected to remain frozen, given the probable delay between recapture, transport to research institute and analysis. 
The defrosting method varied slightly between countries. Danish and Polish samples were defrosted at room temperature overnight (14-16 h in Denmark, 16-18 h in Poland). Swedish recaptures were removed from the freezer in the morning and left to defrost at room temperature for $4-8 \mathrm{~h}$. German samples were placed in cold storage $\left(0-4^{\circ} \mathrm{C}\right)$ overnight $(14-$ $18 \mathrm{~h}$ ) and if fish were not completely defrosted in the morning, they were placed in a bath of cold, fresh water while still individually wrapped in plastic bags. In all cases, samples were only processed if completely defrosted.

Post defrost measurements involved recording total length $\left(L_{\mathrm{T}}\right)$, standard length $\left(L_{\mathrm{Tt}}\right)$ and total mass $\left(M_{\mathrm{Tt}}\right)$ of thawed (subscript $\mathrm{t}$ ) fish and the same parameters for thawed and gutted fish (subscript tg). For samples collected by Germany, $M_{\mathrm{t}}$ and $M_{\mathrm{tg}}$ were measured using a Sartorius (www.essenbioscience.com) SEB3DCS-1000T scale (weighing range $0.1 \mathrm{~g}-3 \mathrm{~kg}$, accuracy $0.1 \mathrm{~g}$ ); samples from all other countries were weighed using the same scales described previously. For the tagging study, $L_{\mathrm{S}}$ is generally used only if the tail is too damaged to measure $L_{\mathrm{T}}$ accurately. In addition, all samples collected by Poland in March and a subsample of fish collected in February $(n=118)$ were defrosted and length measurements were taken after 5 days (only $L_{\mathrm{Ta}}$ and $L_{\mathrm{Tt}}$ measurements were recorded for this sub-sample).

\subsection{Relationship between dead and live measurements}

To investigate whether changes in length and mass occurred after death but prior to freezing, the data from sampling events when measurements were recorded both live, at time of capture, and $1 \mathrm{~h}$ after death $(n=494)$ were analysed. The percentage change $(\Delta \%)$ in $L_{\mathrm{T}}$ for each individual fish (i) measured when alive (a) and $1 \mathrm{~h}$ after death (d) was estimated:

$\Delta \%_{\left(L_{\mathrm{Tai}}, L_{\mathrm{Tdi}}\right)}=100\left(L_{\mathrm{Tdi}}-L_{\mathrm{Tai}}\right) L_{\mathrm{Tai}}^{-1}$ and $\Delta \%_{\left(M_{a}, W M_{d}\right)} \Delta \%_{\left(M_{\mathrm{Tai}}, M_{\mathrm{Tdi}}\right)}=100\left(M_{\mathrm{Tdi}}-\right.$ $\left.M_{\mathrm{Tai}}\right) M_{\mathrm{Tai}}{ }^{-1}$. 
Graphical data exploration revealed several outliers within the $\Delta \%_{\left(L_{\mathrm{Tai}}, L_{\mathrm{Tdi}}\right)}$ and $\Delta \%_{\left(M_{\mathrm{Tai}}, M_{\mathrm{Tdi}}\right)}$ data. All data that were more than $2 \mathrm{SD}$ from the mean $\Delta \%_{\left(L_{\mathrm{Tai}}, L_{\mathrm{Tdi}}\right)}$ and $\Delta \%_{\left(M_{\mathrm{Tai}}, M_{\mathrm{Tdi}}\right)}$ were re-examined to assess whether they should be considered typographic or recording errors and thus justifiably removed from the dataset. Simple transcription errors were corrected through cross-checking with field protocols. However, errors caused by indistinct calling by the measurer or misunderstanding of the recorder, which is a common source of error when working at sea, were less straightforward to identify (Holden \& Raitt, 1974). For each individual in this experiment up to four sets of measurements were recorded (live, $1 \mathrm{~h}$ after death, thawed and gutted) and these allowed for cross-checking for plausibility across repeated measurements of the same variable taken and different times. Visually assessing the relationships between variables, for example between $L_{\mathrm{T}}$ and $M_{\mathrm{T}}$ and between $L_{\mathrm{T}}$ and $L_{\mathrm{S}}$, offered another method for detecting outliers that were likely to be caused by recording errors. Outliers were considered errors and removed if the measurement was impossible (e.g., a $L_{\mathrm{S}}$ measurement much larger than $L_{\mathrm{T}}$ measurements of that fish, or an $M_{\mathrm{Ttg}}$ greater than a $M_{\mathrm{Tt}}$ ), or highly implausible (e.g., a clear outlier in the shrinkage relationship and the length-mass relationship for one set of measurements, but none of the other sets). Four data recording errors were detected and removed in this way.

Paired-samples $t$-tests revealed significant differences between $L_{\mathrm{Ta}}$ and $L_{\mathrm{Td}}$ and between $M_{\mathrm{Ta}}$ and $M_{\mathrm{Td}}(\S 3)$; therefore, a linear model was used to describe the relationship between $L_{\mathrm{Ta}}$ and $L_{\mathrm{Td}}$ or $M_{\mathrm{Ta}}$ and $M_{\mathrm{Td}}$. These linear models were used to predict the $L_{\mathrm{Ta}}$ and $M_{\mathrm{Ta}}$ of individuals for which only $L_{\mathrm{Td}}$ and $M_{\mathrm{Td}}$ were recorded $(n=105)$, so that these data could also be included in subsequent analyses.

\subsection{Percentage change in $L_{\mathrm{T}}$ and $M_{\mathrm{T}}$}


The $\Delta \%$ in $L_{\mathrm{T}}$ after thawing was estimated for each defrosted fish (subscript i) as: $\Delta \%_{\left(L_{\mathrm{Tai}}, L_{\mathrm{Tti}}\right)}=100\left(L_{\mathrm{Tti}}-L_{\mathrm{Tai}}\right) L_{\mathrm{Tai}}{ }^{-1} ; L_{\mathrm{Tt}}$ was replaced by $L_{\mathrm{Ttg}}, L_{\mathrm{St}}$ and $L_{\mathrm{Stg}}$ to calculate $\Delta \%_{\left(L_{\mathrm{Ta}}, L_{\mathrm{Ttg}}\right)}, \Delta \%_{\left(L_{\mathrm{Ta}}, L_{\mathrm{St}}\right)}$ and $\Delta \%_{\left(L_{\mathrm{Ta}}, L_{\mathrm{Stgi}}\right)}$, respectively. The $\Delta \%_{\left(M_{\mathrm{Ta}}, M_{\mathrm{Tt}}\right)}$ and $\Delta \%_{\left(M_{\mathrm{Ta}}, M_{\mathrm{g}}\right)}$ were estimated in the same way. A negative $\Delta \%$ corresponded to a decrease in $L_{\mathrm{T}}$ or $M$ after frozen storage. Several outliers were apparent in the dataset (Figure 2) and were probably related to data input errors. The methods described in the previous sub-section for assessing outlier plausibility were applied to all variations of $\Delta \%$ and impossible or implausible outliers were removed from subsequent analysis. Twenty recording errors were detected and removed (Figure 2). Additionally, $M_{\mathrm{T}}$ measurements for the largest individual in the dataset $\left(M_{\mathrm{Ta}}=\right.$ 6900g; Figure 2) were excluded, as they were disproportionately influential on the models fitted. As no other data for such large fish were available, this individual could not be assumed to be representative of all fish in this size range.

The variables $L_{\mathrm{Ta}}$ and $M_{\mathrm{Ta}}$ were centred (subscript c) $\left(L_{\mathrm{TCa}}=L_{a \mathrm{Ta}}-\bar{L}_{\mathrm{Ta}} ; M_{\mathrm{Ca}}=\right.$ $\left.M_{a}-\bar{M}_{a}\right)$. Linear regressions between $\Delta \%_{\left(L_{\mathrm{Ta}}, L_{\mathrm{Tt}}\right)}$ and $L_{\mathrm{TCa}}$ were used to assess whether $\Delta \%_{\left(L_{\mathrm{Ta}}, L_{\mathrm{Tt}}\right)}$ was length-dependent: $\Delta \%_{\left(L_{\mathrm{Tai}}, L_{\mathrm{Tti}}\right)}=\alpha+\beta L_{T C a i}+\varepsilon_{i}$, where $\varepsilon_{i} \sim N\left(0, \sigma^{2}\right)$ and linear regressions between $\%$ change $e_{\left(W_{a}, W_{t}\right)}$ and $M c_{\mathrm{T} a}$ were used to assess whether $\Delta \%_{\left(M_{\mathrm{a}}, M_{\mathrm{t}}\right)}$ was mass-dependent. The intercepts of these models $(\alpha)$ indicated whether the average $\Delta \%$ was significantly different from zero ( $\beta$ is the slope, $\varepsilon$ is the error term).

\section{4 | Influence of time spent frozen on length}

Analysis of variance (ANOVA) was used to test the relationships between $\Delta \%_{\left(L_{\mathrm{Ta}}, L_{\mathrm{Tt}}\right)}$ and the factorial variable time frozen (5 days, 1 month or 4 months). $\Delta \%_{\left(L_{\mathrm{Ta}}, L_{\mathrm{Tt}}\right)}=\alpha+t_{\mathrm{fzi}}+\varepsilon_{i}$ where $\varepsilon_{i} \sim N\left(0, \sigma^{2}\right)$, where $t_{\mathrm{fz}}$ is the time spent frozen. To assess whether there were 
significant pairwise differences between each combination of freezing durations, Tukey's multiple comparison procedure was employed to adjust $P$-values for multiplicity, using the multcomp package in R (Bretz et al., 2010; Hothorn et al., 2008).

\subsection{Influence of other variables on percentage change in length and mass}

In addition to time spent frozen, there are other variables present in the dataset that also have the potential to influence $\Delta \%_{\left(L_{\mathrm{Ta}}, L_{\mathrm{Tt}}\right)}$ and $\Delta \%_{\left(M_{\mathrm{a}}, M_{\mathrm{t}}\right)}$, namely region of capture (represented by sampling country; Figure 1) and condition at capture. Individual condition factors were estimated for each fish as Fulton's condition factor: $K=100\left(M_{\mathrm{a}} L_{\mathrm{Ta}}{ }^{-3}\right)$. This will vary with length when the length-mass relationship is not isometric (Le Cren, 1951), but for the cod used in this analysis the exponent of the length-mass relationship (2.98) was very close to 3.0. Therefore, for comparisons of condition between individuals from this study, Fulton's $K$ was considered a reasonable metric. One outlier with $K<0.2$ and two with $K \approx 2$ were removed from the dataset, as these values are biologically impossible. As the calculation of $K$ requires a mass measurement, only individuals which were weighed at capture could be included in this analysis ( $n=748$; excluding all fish defrosted after 5 days and fish caught by Germany in January).

A model selection procedure was used to find the optimal model, including the parameters which best explain the variation in $\Delta \%_{\left(L_{T a}, L_{T t}\right)}$. The three explanatory variables mentioned above were included in this model selection process, so that the most complex model fitted was: $\Delta \%_{\left(L_{\mathrm{Ta}}, L_{\mathrm{Tt}}\right)}=\alpha+t_{\mathrm{fzi}}+$ region $_{i}+\beta K_{i}+\varepsilon_{i}$ where $\varepsilon_{i} \sim N\left(0, \sigma^{2}\right)$

The $\Delta \%_{\left(L_{\mathrm{Ta}}, L_{\mathrm{Tt}}\right)}$ after 5 days in the freezer were not included in these models, as mass measurements were not taken for fish frozen for only 5 days; thus, $K$ could not be calculated. 
Models were fit with all combinations of these predictors and Aikake's information criterion (AIC) was used to compare the goodness of fit of each model (Table 2).

The same procedure was used to find the best fitting model for explaining $\Delta \%_{\left(M_{a_{i}}, M_{\mathrm{ti}}\right)}($ Table 3$)$. Also, the relationship between condition factor and region of capture was examined using ANOVA: $K_{i}=\alpha+$ region $_{i}+\varepsilon_{i}$ where $\varepsilon_{i} \sim N\left(0, \sigma^{2}\right)$. For models including the variable region, pairwise differences between each region were assessed using Tukey's multiple comparison procedure to adjust $P$-values for multiplicity using the multcomp package in R (Bretz et al., 2010; Hothorn et al., 2008)).

\section{5 | Relationship between thawed and live measurements}

Linear models were used to model the relationship between $L_{\mathrm{Ta}}$ and $L_{\mathrm{Tt}}, L_{S \mathrm{t}}, L_{\mathrm{Ttg}}$ or $L_{S \mathrm{tg}}$ and between $M_{\mathrm{Ta}}$ and $M_{\mathrm{t}}$ or $M_{\mathrm{tg}}$. The model outputs were used to construct conversion equations. Linear model assumptions were checked throughout using graphical exploration of residuals. All statistical analyses were carried out using R 3.5.0 (www.r-project.otg).

\section{3 | RESULTS}

The number of samples collected per country per month ranged from 39 to 279 individuals

(Table 1). $L_{\mathrm{Ta}}$ of cod collected ranged from $161 \mathrm{~mm}$ to $890 \mathrm{~mm}$ (mean $\left.=334 \mathrm{~mm}\right)$ and $M_{\mathrm{Ta}}$ ranged from 45 to $6900 \mathrm{~g}$ (mean $=351 \mathrm{~g}$ ).

\section{1 | Relationship between dead and live measurements}


The $L_{\mathrm{Ta}}$ of cod measured both live and $1 \mathrm{~h}$ after death ranged from $176 \mathrm{~mm}$ to $525 \mathrm{~mm}$ (mean $=315 \mathrm{~mm}$ ) and $M_{\mathrm{Ta}}$ ranged from 45 to $1385 \mathrm{~g}$ (mean $=303 \mathrm{~g}$ ). There was a significant

difference between live measurements and those taken 1 hour after death. On average $L_{\mathrm{Td}}$ was $1.18 \mathrm{~mm}$ shorter than $L_{\mathrm{Ta}}(t=11.12, d f=492, P<0.001)$, corresponding to an average $\Delta \% L_{\mathrm{Ta}}, L_{\mathrm{Td}}$ of $-0.40 \%$. On average $M_{\mathrm{Td}}$ was $2.70 \mathrm{~g}$ less than $M_{\mathrm{Ta}}(t=16.67, d f=490, P<$ $0.001)$, corresponding to an average $\Delta \% M_{\mathrm{a}}, M_{\mathrm{d}}$ of $-0.50 \%$. The relationship between $L_{\mathrm{Ta}}$ and $L_{\mathrm{Td}}$ was estimated to be: $L_{\mathrm{Ta}}(\mathrm{mm})=0.998( \pm 0.002) L_{\mathrm{Td}}+1.840( \pm 0.500), F_{1,491}=4.09 \mathrm{x}$ $\left.10^{5}, P<0.001\right)$ and the relationship between $M_{\mathrm{Ta}}$ and $M_{\mathrm{Td}}: M_{\mathrm{Ta}}(\mathrm{g})=1.007( \pm 0.0007) M_{\mathrm{Td}}+$ $\left.0.55( \pm 0.27), F_{1,489}=1.80 \times 10^{6}, P<0.001\right)$. These functions were used to convert $L_{\mathrm{Td}}$ and $M_{\mathrm{Td}}$ to $L_{\mathrm{Ta}}$ and $M_{\mathrm{Ta}}$, in cases where live measurements had not been recorded (all samples provided by Denmark in April and 34 individuals provided by Germany in May; $n=105$ ).

\subsection{Percentage change in $L_{T}$ and $M_{T}$}

There was no significant relationship between $L_{\mathrm{TCa}}$ and $\Delta \% L_{\mathrm{Tai}}, L_{\mathrm{Tti}}\left(F_{1,921}=2.65, P>0.05\right)$. The intercept was significantly different from $0(P<0.001)$ and indicated that mean $( \pm$ SD $)$ $\Delta \% L_{\mathrm{T} \text { ai }}, L_{\mathrm{Tti}}$ was $-2.91 \pm 0.05 \%$. There was also no significant relationship between $M_{\mathrm{TCa}}$ and $\Delta \% M_{\mathrm{ai}}, M_{\mathrm{ti}}\left(F_{1,742}=1.414, P>0.05\right)$. The mean $\Delta \% M_{\mathrm{a}}, M_{\mathrm{t}}$ was $-2.65 \% \pm 0.14 \%(P<0.001)$. As no size dependent shrinkage was found in the dataset, size was not included as an explanatory variable in subsequent models.

\subsection{Influence of time spent frozen on length}

There was a significant relationship between $\Delta \% L_{\mathrm{Ta}}, L_{\mathrm{Tt}}$ and time spent frozen $\left(F_{2,920}=18.1\right.$, $P<0.001$ ), where $\Delta \% L_{\mathrm{Ta}}, L_{\mathrm{Tt}}$ of cod frozen for only 5 days (mean $\pm \mathrm{SD}=-2.18 \pm 0.13 \%$ ) was 
significantly less than cod frozen for 1 month $(-2.95 \pm 0.15 \%)$ or 4 months $(-3.10 \pm 0.16 \%$;

Figure 3 ). The difference in $\Delta \% L_{\mathrm{Ta}}, L_{\mathrm{Tt}}$ between 1 months and 4 months freezing was nonsignificant $(P>0.05)$.

\subsection{Influence of other variables on percentage change}

Average $K$ of sampled cod ranged from 0.77 in the Bornholm Basin (Danish samples), to 0.82 in Hanö Bay (Swedish samples), 0.88 in Gdańsk Bay (Polish samples) and 0.94 in the Arkona Basin (German samples). The differences in $K$ between regions were significant (Supporting Information Table S1).

The best fitting model for explaining $\Delta \% L_{\mathrm{Ta}}, L_{\mathrm{Tt}}$ included region of capture and $K\left(F_{4,740}=\right.$ 21.8, $P<0.001)$, but including time spent frozen did not improve model fit $(\Delta \mathrm{AIC}<2$; Table 2). This model indicated that $\Delta \% L_{\mathrm{Ta}}, L_{\mathrm{Tt}}$ varied significantly between cod captured from different regions and there was a negative relationship between $K$ and $\Delta \% L_{\mathrm{Ta}}, L_{\mathrm{Tt}}$ (Table 4 ). There were significant differences in $\Delta \% L_{\mathrm{Ta}}, L_{\mathrm{Tt}}$ between all regions, except Hanö Bay and Gdańsk Bay (Supporting Information Table S2).

The best fitting model for explaining $\Delta \% M_{\mathrm{Ta}}, M_{\mathrm{Tt}}$ included the variables $K$ and region of capture, but did not include time spent frozen (Table 3). This model indicated that similarly to the results for $\Delta \% L_{\mathrm{Ta}}, L_{\mathrm{Tt}}$, there was a negative relationship between $\Delta \% M_{\mathrm{Ta}}, M_{\mathrm{Tt}}$ and $K$. Loss of mass was significantly reduced in fish captured in Gdańsk Bay, compared with fish sampled from all other regions (Table 5 and Supporting Information Table S3). However, there was no significant difference in the $\Delta \% M_{\mathrm{Ta}}, M_{\mathrm{Tt}}$ between fish sampled from the other regions (Supporting Information Table S3).

\section{5 | Relationship between thawed and live measurements}


The data for 1 and 4 months were pooled together for estimation of conversion equations, as the $\Delta \% M_{\mathrm{Ta}}, M_{\mathrm{Tt}}$ and $\Delta \% L_{\mathrm{Ta}}, L_{\mathrm{Tt}}$ did not vary significantly between these frozen storage times (Figure 3). The data for fish frozen for 5 days were not included in the estimation of conversion equations, as this subsample was only collected from one region and it is not possible to disentangle the effect of this short freezing time from other variables which may influence shrinkage.

The conversion equations from simple linear models to estimate $L_{\mathrm{Ta}}$ from measured thawed lengths are as follows:

$$
\begin{aligned}
& L_{\mathrm{Ta}}=1.02( \pm<0.01) L_{\mathrm{Tt}}+2.08( \pm 0.77), F_{1,803}=1.89 \times 10^{5}, P<0.001 ; \\
& L_{\mathrm{Ta}}=1.11( \pm<0.01) L_{S \mathrm{t}}+5.48( \pm 0.89), F_{1,799}=1.39 \times 10^{4}, P<0.001 ; \\
& L_{\mathrm{Ta}}=1.02( \pm<0.01) L_{\mathrm{Ttg}}+1.82( \pm 0.70), F_{1,601}=2.12 \times 10^{5}, P<0.001 ; \\
& L_{\mathrm{Ta}}=1.11( \pm<0.01) L_{\mathrm{Stg}}+5.22( \pm 0.98), F_{1,601}=1.06 \times 10^{5}, P<0.001 .
\end{aligned}
$$

The conversion factors from simple linear models to estimate $M_{\mathrm{Ta}}$ from each of the measured thawed mass are as follows:

$$
\begin{aligned}
& \left.M_{\mathrm{Ta}}=1.03( \pm<0.01) M_{\mathrm{t}}-1.47( \pm 0.78), F_{1,742}=3.02 \times 10^{5}, P<0.001\right) \\
& \left.M_{\mathrm{Ta}}=1.24( \pm<0.01) M_{\mathrm{tg}}-6.70( \pm 1.98), F_{1,694}=4.93 \times 10^{4}, P<0.001\right)
\end{aligned}
$$

\section{4 | DISCUSSION}

Whole Baltic cod frozen for a period of 5 days to 4 months changed in length on average by $2.91 \%$, similar to previously published estimates for North-west Atlantic cod, which also changed in length by $-2.9 \%$ on average after $8-57$ days frozen storage (Halliday \& Roscoe, 1969). Whole mass $\left(M_{\mathrm{T}}\right)$ of Baltic cod changed on average by $-2.65 \%$ following frozen storage of 1 or 4 months. This is similar to the observed $-2.7 \%$ mass loss of frozen cod fillets 
after 36 days of frozen storage (Dunn \& Rustad, 2007), but is considerably more than the $0.5 \%$ average mass loss reported for whole North-west Atlantic cod frozen for 8 to 57 days (Halliday \& Roscoe, 1969). If not corrected for, shrinkage will introduce a directional bias into analyses conducted using data from frozen cod. The effects could be particularly noticeable when using tag-recapture data to estimate growth of these slow growing fish, but there are other applications in fisheries science requiring mass-length measurements from frozen cod that may also be affected. Therefore, in situations where it is not possible to measure fresh length and mass of fish, the conversion equations estimated here can be used to convert thawed length of Baltic cod to live length. Additional equations are also provided which can be used to convert post-mortem measurements of cod to estimates of live length and mass. The application of these conversion equations should be restricted to cod within the size range included in this analysis.

We found that length and mass of Baltic cod had already decreased slightly $1 \mathrm{~h}$ after death, prior to freezing. Estimation of live length is important for tagging studies, but as all routine measurements used for stock assessments are made on dead fish, early post-mortem shrinkage should not greatly increase the uncertainty of stock assessments. Our results indicated that shrinkage of Baltic cod continued between death and 1 month frozen storage, but the variations in length and mass shrinkage between 1 and 4 months frozen storage were insignificant. These findings correspond to previous studies on fish shrinkage following freezing. Shrinkage of pink snapper Chrysophrys auratus (Forster 1801) was most rapid during the first $6 \mathrm{~h}$ post-mortem and though further shrinkage was minimal after $24 \mathrm{~h}$, some individuals continued to shrink up to $168 \mathrm{~h}$ post-mortem (Morison, 2004). There was no difference in the length shrinkage of ruffe Gymnocephalus cernus (L. 1758) that had been stored in a freezer for 75,148 or 301 days, though mass decreased with increasing time in the freezer (Ogle, 2009). North-west Atlantic cod continued to shrink in length as time frozen 
increased over a 57 day experimental period but change in mass was variable and without a consistent trend and sample sizes were perhaps too small to draw reliable conclusions (Halliday \& Roscoe, 1969). It has been reported previously that most freezing induced water losses in cod filets occur within the first 20 days of freezing (LeBlanc et al., 1988). Our findings indicated that most shrinkage in Baltic cod occurred within the first month postmortem and freezing and at some point between 1 and 4 months frozen storage shrinkage rates began to decrease and perhaps cease.

A significant negative relationship between condition factor and change in length and mass of Baltic cod was observed. The water content of cod muscle is increased relative to the lipid content in very thin, starved cod (Love 1958, 1962, Lambert \& Dutil, 1997). This rather suggests that change in length and mass should be positively related to condition, given the increased potential for liquid loss from the muscles of very low condition cod. However, the negative correlation between condition factor and percentage water content of muscle only holds true until a condition factor of around 0.7 is reached, after which water content of muscle remains relatively stable regardless of increasing condition factor (Lambert \& Dutil, 1997). As the majority of cod used in this study had $K>0.7$ (regional averages ranged from $K=0.77$ to 0.94 ), there must be another mechanism relating condition to shrinkage. For example, it is well documented that fish muscles contract post-mortem, a process that can result in gaping of fillets (Burt et al., 1970). It has been previously reported that gaping of cod fillets is more pronounced in healthy, good condition individuals than in weak, poor condition fish, due to stronger muscle contractions in better condition individuals (Love \& Robertson, 1968). Additionally, well-fed fish have high muscle glycogen (Martinez et al., 2003), which results in low pH in the post-mortem flesh (Black \& Love, 1988) as the glycogen is degraded anaerobically. The post-mortem $\mathrm{pH}$ of cod muscle has been shown to greatly influence the texture of the muscle, with low $\mathrm{pH}$ resulting in tougher texture, 
shrinkage of the muscle myofibrils, increased liquid loss and increased fillet gaping (Love, 1975, Ofstad et al., 1996), all factors that potentially could contribute to the length and mass shrinkage of fish.

Significant regional differences in length shrinkage of cod between the four sampling regions in the Baltic Sea were observed and cod sampled from the Gdańsk Bay region were found to lose significantly less mass than fish from the other regions. Significant regional differences in condition factor of sampled fish were detected and are probably linked to regional differences in food availability and quality, parasite infestation rates and mixing proportions of Western and Eastern Baltic cod present in the samples (Casini et al., 2016, Eero et al., 2012, 2014, 2015, Horbowy et al., 2016). However, the best fitting models describing variation in length and mass shrinkage included both condition factor and region as explanatory variables, indicating that additional regional variation was present within the dataset. Using the available data, it is difficult to completely disentangle the causes of the additional regional variation in shrinkage, which may be due to a combination of factors such as variation in muscle water content and tissue composition of individual fish, regional environmental conditions and handling and storage procedures of different sampling countries.

For example, although efforts were made to achieve balanced sampling throughout the year, samples were collected from the different regions during different months and so it was not possible to separate seasonal and regional effects. Muscle $\mathrm{pH}$ varies with season and the reproductive cycle of cod (Love, 1975, 1979), as does the water, fat and protein content of the muscle tissue (Dambergs, 1964). Given the mechanisms discussed above, shrinkage could therefore also be expected to vary throughout the year. Additionally, warmer ambient temperatures facilitate increased water loss, as higher initial temperatures reduce the freezing rate of fish muscle (Long, 1955). Slower freezing rates result in an increase in thaw exudates 
and thus mass loss due to the formation of large ice crystals in extracellular areas and the mechanical damage of cells (Mørkøre and Lilleholt, 2007). Therefore, ambient temperature at date of capture could contribute to shrinkage rate, with potentially increased shrinkage of cod caught during summer compared to winter. Colder ambient temperatures prior to freezing may have potentially contributed to the significantly reduced mass loss of fish captured in Gdańsk Bay for example, as these were mostly caught in February (Table 1). Furthermore, February is well outside the main spawning season of cod in the eastern Baltic Sea (mid-June to mid-September, Wieland et al., 2000). Water content of cod muscle is highest during the spawning period (Bogucki and Trzesinski, 1949; Dambergs, 1964; Love, 1960) and the muscle water content in cod in the eastern Baltic Sea is thus lower in February than in May to September (Bogucki and Trzesinski, 1949), potentially contributing to reduced mass loss.

Another factor that could introduce variation into the dataset used in this study, is the presence of cod from both Baltic Sea stocks within the dataset. In this study, samples were collected from the main distribution area of the Eastern Baltic cod stock. The Western Baltic cod stock mainly inhabits the sea west of the sampling area, but there is also considerable mixing and overlap between the two cod stocks, especially in Arkona Bay (subdivision24) region (Hüssy et al., 2016, Hemmer-Hansen et al., 2019, Weist et al., 2019), from which the German samples originated. Therefore, it is likely that a subset of cod included in this study belonged to the Western stock and that the proportion of the two stocks present in samples varied regionally. The two cod stocks are genetically distinct, with genomic divergence related to adaptation to habitat differences in salinity, oxygen and temperature (Berg et al., 2015). It is not clear how such genetic differences may influence freezing induced shrinkage, but any population-specific differences in body composition could play a role. cod from the Baltic stocks are morphometrically very similar, but some differences have been reported, for example in the mass-length coefficients and head shape (Berner \& Vaske, 1985). 
Morphometric differences that result in a difference in volume-to-surface-area may lead to differences in shrinkage (Florin \& Lingman, 2008). In addition, the two cod stocks differ in their spawning time (Hüssy 2011), so body composition in relation to season will also vary between stocks. As population differences cannot be ruled out as a possible contributing factor to the variation in shrinkage observed in this study, the conversion factors should be considered representative of cod inhabiting the sampled regions, rather than specifically cod belonging to the eastern or western Baltic stock. However, given the similarities found between shrinkage of cod in this study and reported for cod in the North-west Atlantic Ocean (Halliday \& Roscoe, 1969), it is possible that shrinkage may be species rather than population-specific.

It is likely that other factors also contributed to the variable shrinkage of Baltic cod. For example, thawing frozen fish in fresh water reduces mass loss and could explain the differences in mass loss observed between this study and previously published estimates from North-west Atlantic cod (Halliday \& Roscoe, 1969). Ambient temperature and method of thawing can influence the quality of defrosted tissues of frozen fish, in terms of $\mathrm{pH}$, liquid loss, texture and membrane integrity (Nilsson \& Ekstrand, 1995, Javadian et al., 2013). Additionally, the level of stress experienced during handling prior to death can accelerate rigor mortis (Kristoffersen et al., 2006), strenuous activity increases the lactic acid content and thus decreases the $\mathrm{pH}$ of cod muscle (Beamish, 1968), airtight wrapping of fish during freezing can decrease water loss and thus shrinkage (Boyd et al., 1967) and the time lapse between death and freezing can contribute to the degree of shrinkage (Love \& Robertsen, 1968). These factors were not rigorously controlled for between sampling regions in this study. Human induced error factors or equipment problems can also not be completely ruled out (Bunch et al., 2013). However, such variability will be impossible to avoid in tagging studies that rely on recaptured fish provided by a range of different sources including 
commercial fishing vessels from different countries, anglers and research vessels. These sources of error and uncertainty should be kept in mind when back-calculating live length of fish from defrosted samples, but for practical purposes the overall conversion equations, which encompass all the variability present in this extensive dataset, are of the most use.

\section{ACKNOWLEDGEMENTS}

Thanks go to all technical staff involved in the collection and processing of samples used in this study. Thanks go also to L. Schmidt for conducting a preliminary literature review and S. Haase for constructive comments on a previous draft of the manuscript.

\section{REFERENCES}

Beamish, F.M. .H. (1968). Glycogen and lactic acid concentration in Atlantic cod (Gadus morhua) in relation to exercise. Journal of the Fisheries Research Board of Canada, 25, $837-851$

Berg, P.R., Jentoft, S., Star, B., Ring, K.H., Knutsen, H., Lien, S., Jakobsen, K.S. \& Andre, C., (2015). Adaptation to low salinity promotes genomic divergence in Atlantic cod (Gadus morhua L.). Genome biology and evolution, 7, 1644-1663

Berner, M., \& Vaske, B. (1985). Morphometric and meristic characters of cod stocks in the Baltic Sea. ICES Document CM 1985/J: 11.

Black, D. \& Love, R.M. (1988). Estimating the carbohydrate reserves in fish. Journal of Fish Biology, 32, 335-340

Bogucki, M., \& Trzesinski, P. (1950). Fluctuations in the water and fat content of the cod. ICES Journal of Marine Science, 16, 208-210

Boyd, J. $M_{\mathrm{T}}$., Southcott, B.A. \& Boothby, G.F. (1967). Desiccation of frozen fish. Journal of the Fisheries Board of Canada, 24, 211-212. 
Bretz, F., Hothorn, T. \& Westfall, P., (2010). Multiple Comparisons Using R. CRC Press, Boca Raton, FL.

Buchheister, A. \& Wilson, MT. (2005). Shrinkage correction and length conversion equations for Theragra chalcogramma, Mallotus villosus and Thaleichthys pacificus. Journal of Fish Biology, 67, 541-548

Bunch, A.J., Walters, C.J. \& Coggins, L.G. (2013). Measurement error in fish lengths: evaluation and management implications. Fisheries, 38, 320-326

Burt, J.R., Jones, N.R., McGill, A.S. \& Stroud, G.D. (1970). Rigor tensions and gaping in cod muscle. International Journal of Food Science and Technology, 5, 339-351

Casini, M., Käll, F., Hansson, M., Plikshs, M., Baranova, T., Karlsson, O., Lundström, K., Neuenfeldt, S., Gårdmark, A. \& Hjelm, J. (2016). Hypoxic areas, densitydependence and food limitation drive the body condition of a heavily exploited marine fish predator. Royal Society Open Science, 3, https://doi.org/10.1098/rsos.160416

Dambergs, N. (1964). Extractives of fish muscle. 4. Seasonal variations of fat, watersolubles, protein and water in cod (Gadus morhua L.) fillets. Journal of the Fisheries Research Board of Canada, 21, 703-709.

Dunn, A.S. \& Rustad, T. (2007). Quality changes during superchilled storage of cod (Gadus morhua) fillets. Food Chemistry, 105, 1067-1075

Eero, M., Hemmer-Hansen, J. \& Hüssy, K., (2014). Implications of stock recovery for a neighbouring management unit: experience from the Baltic cod. ICES Journal of Marine Science, 71, 1458-1466

Eero, M., Hjelm, J., Behrens, J., Buchmann, K., Cardinale, M., Casini, M., Gasyukov, P., Holmgren, N., Horbowy, J., Hüssy, K., Kirkegaard, E., Kornilovs, G., Krumme, U., Köster, F.M.T., Oeberst, R., Plikshs, M., Radtke, K., Raid, T., Schmidt, J., Tomczak, 
M.T., Vinther, M., Zimmermann, C. \& Storr-Paulsen, M. (2015). Eastern Baltic cod in distress: biological changes and challenges for stock assessment. ICES Journal of Marine Science, 72, 2180-2186

Eero, M., Vinther, M., Haslob, H., Huwer, B., Casini, M., Storr-Paulsen, M. \& Köster, F.M. ., (2012). Spatial management of marine resources can enhance the recovery of predators and avoid local depletion of forage fish: Spatial management of marine ecosystem. Conservation Letters, 5, 486-492

Florin, A.-B. \& Lingman, A. (2008). Shrinkage of flounder Platichthys flesus (L.) and turbot Psetta maxima (L.) following freezing. Journal of Fish Biology, 72, 731-736

Halliday, R.G. \& Roscoe, B. (1969). The effects of icing and freezing on the length and weight of groundfish species. ICNAF Research Document No. 69/2. Redbook Park, IL: International Commission on Northwest Atlantic Fisheries.

Hemmer-Hansen, J., Hüssy, K., Baktoft, H., Huwer, B., Bekkevold, D., Haslob, H., Herrmann, J.-P., Hinrichsen, H.-H., Krumme, U., Mosegaard, H., Nielsen, E.E., Reusch, T.B.H., Storr-Paulsen, M., Velasco, A., von Dewitz, B., Dierking, J. \& Eero, M., (2019). Genetic analyses reveal complex dynamics within a marine fish management area. Evolutionary applications, 12, 830-844

Holden, M.J. \& Raitt, D.F.S., 1974. 3. The measurement of fish and shellfish. In: Manual of fisheries science. Part 2-Methods of resource investigation and their application. Documents Techniques FAO sur les Peches (FAO)-Documentos Tecnicos de la FAO sobre la Pesca (FAO).

Horbowy, J., Podolska, M. \& Nadolna-Attyn, K., (2016). Increasing occurrence of anisakid nematodes in the liver of cod (Gadus morhua) from the Baltic Sea: Does infection affect the condition and mortality of fish? Fisheries Research, 179, 98-103 
Hothorn, T., Bretz, F. \& Westfall, P. (2008). Simultaneous inference in general parametric models. Biometrical Journal, 50, 346-363

Hüssy, K., (2011). Review of western Baltic cod (Gadus morhua) recruitment dynamics. ICES Journal of Marine Science, 68, 1459-1471

Hüssy, K., Eero, M. \& Radtke, K. (2018). Faster or slower: has growth of eastern Baltic cod changed? Marine Biology Research, 14, 598-609

Hüssy, K., Hinrichsen, H. H., Eero, M., Mosegaard, H., Hemmer-Hansen, J., Lehmann, A. \& Lundgaard, L. S. (2016). Spatio-temporal trends in stock mixing of eastern and western Baltic cod in the Arkona Basin and the implications for recruitment. ICES Journal of Marine Science, 73, 293-303

Javadian, S.R., Rezaei, M., Soltani, M., Kazemian, M. \& Pourgholam, R. (2013). Effects of thawing methods on chemical, biochemical and microbial quality of frozen whole rainbow trout (Oncorhynchus mykiss). Journal of Aquatic Food Product Technology, 22, 168-177

Johnston, $M_{\mathrm{T}}$.A., Nicholson, F.J, Roger, A. \& Stroud, G.D. (1994). Freezing and refrigerated storage in fisheries. FAO Fisheries Technical Paper. No. 340. Rome, FAO. 1004. $143 \mathrm{p}$.

Kristoffersen, S., Tobiassen, T., Steinsubd, V. \&Olsen, R. L. (2006). Slaughter stress, postmortem muscle $\mathrm{pH}$ and rigor development in farmed Atlantic cod (Gadus morhus L.). International Journal of Food Science and Technology, 41, 861-864

Lambert, Y. \& Dutil, J.-D. (1997). Can simple condition indices be used to monitor and quantify seasonal changes in the energy reserves of Atlantic cod (Gadus morhua)? Canadian Journal of Fisheries and Aquatic Sciences, 54, 104-112

LeBlanc, E.L., LeBlanc, R. \& Blum, I.E. (1988). Prediction of quality in frozen cod (Gadus morhua) fillets. Journal of Food Science, 53, 328-341 
Le Cren, E.D. (1951). The length-weight relationship and seasonal cycle in gonad weight and condition in the perch (Perca fluviatilis). Journal of Animal Ecology, 20, 201-219

Long, R.A.K. (1955). Some thermodynamic properties of fish and their effect on the rate of freezing. Journal of the Science of Food and Agriculture, 6, 621-633

Love, R.M. (1958). Studies on the North Sea cod III. Effects of Starvation. Journal of the Science of Food and Agriculture, 9, 617-620

Love, R.M. (1960). Water content of cod (Gadus callarias L.) muscle. Nature, 185, 692

Love, R.M. (1962). The measurement of "condition" in North Sea cod. ICES Journal of Marine Science, 27, 34-42

Love, R. M. \& Robertson, I. (1968). The connective tissues of fish 1. The influence of biological condition on gaping in frozen - thawed muscle. Journal of Food Science and Technology, 3, 215-221

Love, R.M. (1975). Variability in Atlantic cod (Gadus morhua) from the Northeast Atlantic: a review of seasonal and environmental influences on various attributes of the flesh. Journal of the Fisheries Research Board of Canada, 32, 2333-2342

Love, R.M. (1979). The post mortem pH of cod and haddock muscle and its seasonal variation. Journal of the Science of Food and Agriculture, 30, 433-438

Martinez, M., Gurderley, H., Dutil, J.-D., Winger, P.D., He, P., \& Walsh, S.J. (2003). Condition, prolonged swimming performance and muscle metabolic capacities of cod Gadus morhua. The Journal of Experimental Biology, 206, 503-511

Morison, A.K. (2004). Is rigor mortis the cause of post-mortem shrinkage in juvenile Pagrus auratus? Journal of Fish Biology, 65, 883-888

Mørkøre, T. \& Lilleholt, R. (2007). Impact of freezing temperature on quality of farmed Atlantic cod (Gadus morhua L.). Journal of texture studies, 38, 457-472 
Nilsson, K. \& Ekstrand, B. (1995). Frozen storage and thawing methods affect biochemical and sensory attributes of rainbow trout. Journal of Food Science, 40, 627-630

Ofstad, R., Egelandsdal, B., Kidman, S., Myklebust, R., Olsen, R.L. \& Hermansson, A.M. (1996). Liquid Loss as Effected by post-mortem Ultrastructural Changes in Fish Muscle: Cod (Gadus morhua L) and Salmon (Salmo salar). Journal of the Science of Food and Agriculture, 71, 301-312

Ogle, D.H. (2009). The effect of freezing on the length and weight measurements of ruffe (Gymnocephalus cernus). Fisheries Research, 99, 244-247

Orio, A., Bergström, U., Florin, A.-B., Lehmann, A., Šics, I. \& Casini, M. (2019). Spatial contraction of demersal fish populations in a large marine ecosystem. Journal of Biogeography. https://doi.org/10.1111/jbi.13510

Weist, P., Schade, F.M., Damerau, M., Barth, J.M.I., Dierking, J., André, C., Petereit, C., Reusch, T., Jentoft, S., Hanel, R., \& Krumme, U. (2019). Assessing SNP-markers to study population mixing and ecological adaptation in Baltic cod. PLOS ONE, 14, e0218127. https://doi.org/10.1371/journal.pone.0218127

Wieland, K., Jarre-Teichmann, A., \& Horbowa, K. (2000). Changes in the timing of spawning of Baltic cod: possible causes and implications for recruitment. ICES Journal of Marine Science, 57, 452-464

\section{SUPPORTING INFORMATION}

Supporting information can be found in the online version of this paper. 
TABLE 2 AIC values, degrees of freedom and adjusted $R^{2}$ for model selection of linear model for describing variation in per cent change in length $\left(\Delta \% L_{\mathrm{Ta}}, L_{\mathrm{Tt}}\right)$ of Baltic Gadus morhua. Values in bold give indicate the best fitting models

\begin{tabular}{lccc} 
Variables included & AIC & $\boldsymbol{d} f$ & Adjusted $\boldsymbol{R}^{\mathbf{2}}$ \\
Months frozen $+K+$ region & $\mathbf{2 6 9 6 . 3}$ & 7 & 0.100 \\
$K+$ region & $\mathbf{2 6 9 5 . 4}$ & 6 & 0.100 \\
Months frozen + region & 2702.4 & 6 & 0.090 \\
Months frozen + K & 2772.0 & 4 & $<0.001$ \\
$K$ & 2772.3 & 3 & -0.001 \\
Region & 2702.9 & 5 & 0.090 \\
Months frozen & 2770.3 & 3 & 0.001 \\
\hline$K$, Fulton's condition factor & & &
\end{tabular}


TABLE 3 AIC values, degrees of freedom and adjusted $R^{2}$ for model selection of linear model for describing variation in per cent change in mass $\left(\Delta \% M_{\mathrm{Ta}}, M_{\mathrm{Tt}}\right)$ of Baltic Gadus morhua. Values in bold give indicate the best fitting models

\begin{tabular}{lccc} 
Variables included & AIC & $\boldsymbol{d} f$ & Adjusted $\boldsymbol{R}^{\mathbf{2}}$ \\
Months frozen $+K+$ region & $\mathbf{4 0 9 2 . 0}$ & 7 & 0.070 \\
$K+$ region & $\mathbf{4 0 9 2 . 1}$ & 6 & 0.070 \\
Months frozen + region & 4118.4 & 6 & 0.040 \\
Months frozen $+K$ & 4125.3 & 4 & 0.020 \\
$K$ & 4123.4 & 3 & 0.020 \\
Region & 4114.6 & 5 & 0.040 \\
Months frozen & 4142.1 & 3 & -0.001 \\
\hline$K$, Fulton's condition factor & & &
\end{tabular}


TABLE 4 Parameter estimates for best fitting ANOVA model for describing the variation in per cent change in length $\left(\Delta \% L_{\mathrm{Ta}}, L_{\mathrm{Tt}}\right)$ of Baltic Gadus morhua

\begin{tabular}{lcccr} 
Coefficient & Parameter estimate & Standard error & $\boldsymbol{t}$-value & \multicolumn{1}{c}{$\boldsymbol{P}$} \\
Intercept (Arkona Basin, $K=0)$ & 0.24 & 0.54 & -0.45 & $>0.05$ \\
Bornholm Basin & -1.98 & 0.22 & -9.06 & $<0.001$ \\
Gdańsk Bay & -1.44 & 0.18 & -7.82 & $<0.001$ \\
Hanö Bay & -1.33 & 0.20 & -6.50 & $<0.001$ \\
$K$ & -1.72 & 0.56 & -3.08 & $<0.01$ \\
\hline
\end{tabular}

$K$, Fulton's condition factor 
FIGURE 1 Locations in the Baltic Sea where samples of Gadus morhua were caught by each of the four participating countries. ICES subdivisions are numbered and delimited by white lines.

FIGURE 2 The relationships between: (a) the total length of live $\left(L_{\mathrm{Ta}}\right)$ Baltic Sea Gadus morhua $\left(L_{\mathrm{Ta}}\right.$, measured or back-calculated from total length of dead cod; $\left.L_{\mathrm{Td}}\right)$ and total length of cod after they have been thawed from frozen $\left(L_{\mathrm{Tt}} ; n=925\right)$; (b) $L_{\mathrm{Ta}}$ and total length of thawed and gutted cod $\left(L_{\mathrm{Ttg}} ; n=605\right)$; (c) $L_{\mathrm{Ta}}$ and standard length of live cod $\left(L_{\mathrm{Sa}} ; n=807\right)$; (d) $L_{\mathrm{Ta}}$ and standard length of thawed and gutted cod $\left(L_{\mathrm{Stg}} ; n=605\right)$. Also, The relationship between: (e) the total mass of live Baltic Sea $\operatorname{cod}\left(M_{\mathrm{Ta}}\right.$, measured or back-calculated from total mass of dead $\operatorname{cod} M_{\mathrm{Td}}$ ) and total mass of cod after they have been thawed from frozen $\left(M_{\mathrm{Tt}} ; n=747\right)$; (f) and (f) $M_{\mathrm{Ta}}$ and the total mass of thawed and gutted cod $\left(M_{t g} ; n=699\right) .=-$ =, The one to one relationship between the two variables; - - -, the relationship described in $\S 3.5 ; \bullet$, Data points assumed to be recording errors and were removed before statistical analysis; +. data points for cod measured after only 5 days in the freezer $(n=118)$. 
FIGURE 3: Mean ( \pm SE) per cent change $(\Delta \%)$ in total length (-๑-) of Baltic Sea Gadus morhua at 1 hour after death, after 5 days, 1 month and 4 months frozen storage and the $\Delta \%$ in total mass $(-\Delta-) 1 \mathrm{~h}, 1$ month 4 months frozen storage 


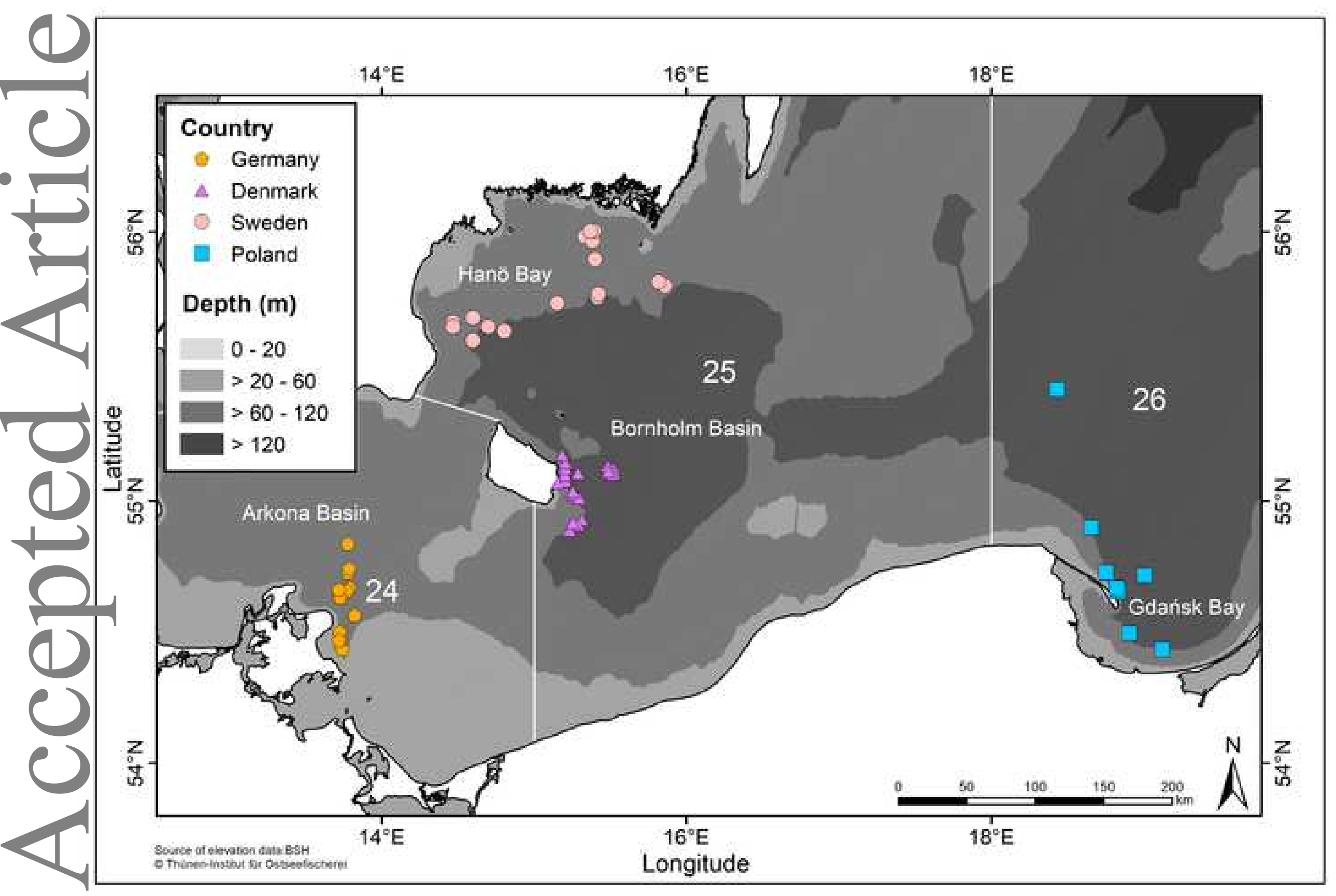

This article is protected by copyright. All rights reserved. 

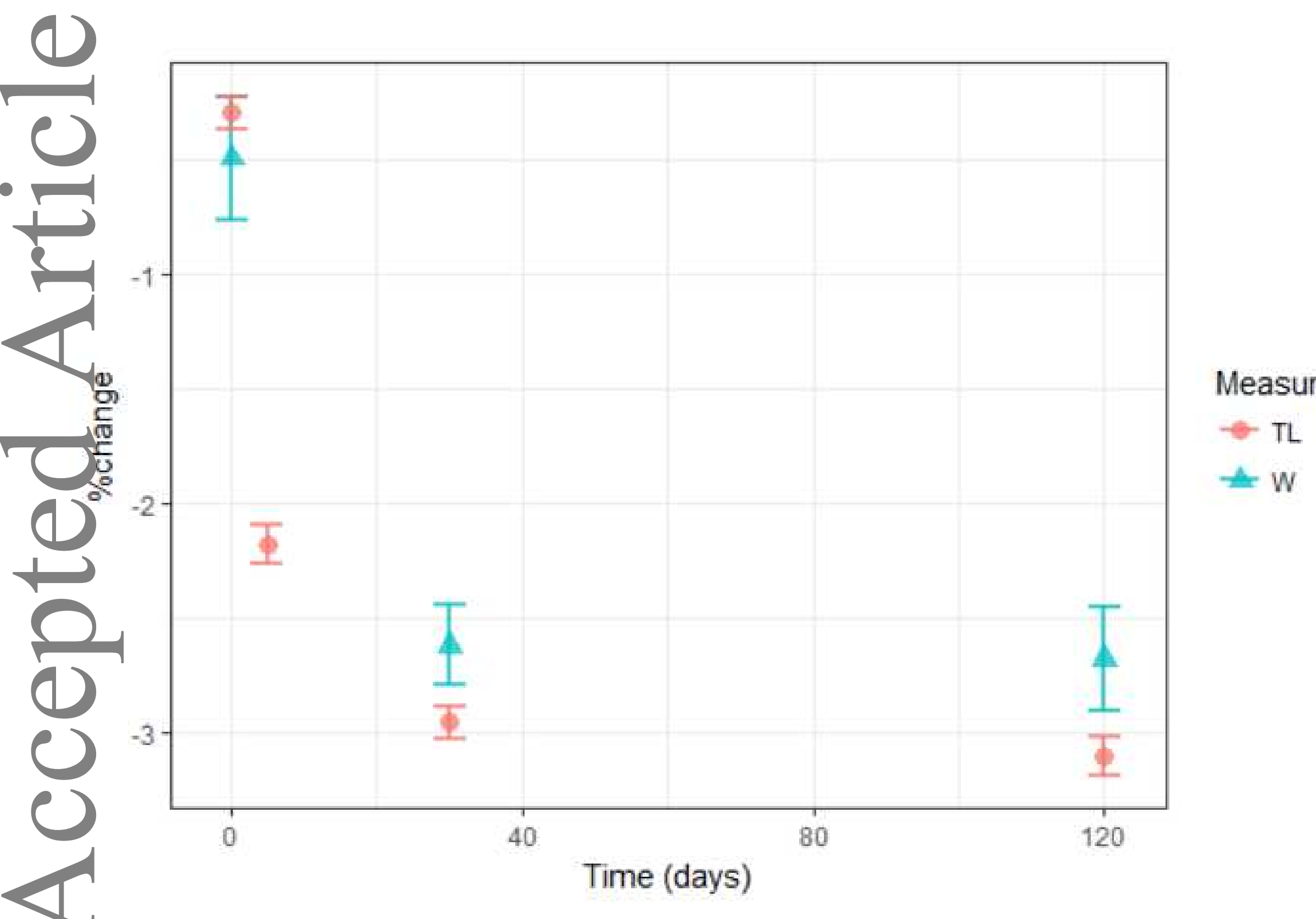

This article is protected by copyright. All rights reserved. 